\title{
REVISITANDO ALGUMAS DAS ATUAIS PERPLEXIDADES DO CONCEITO NORMATIVO DE PROPRIEDADES DE INVESTIMENTO - O CASO PORTUGUÊS
}

\section{REVISING SOME OF THE CURRENT NORMATIVE PERPLEXITIES CONCEPT OF THE INVESTMENT PROPERTY - THE PORTUGUESE CASE}

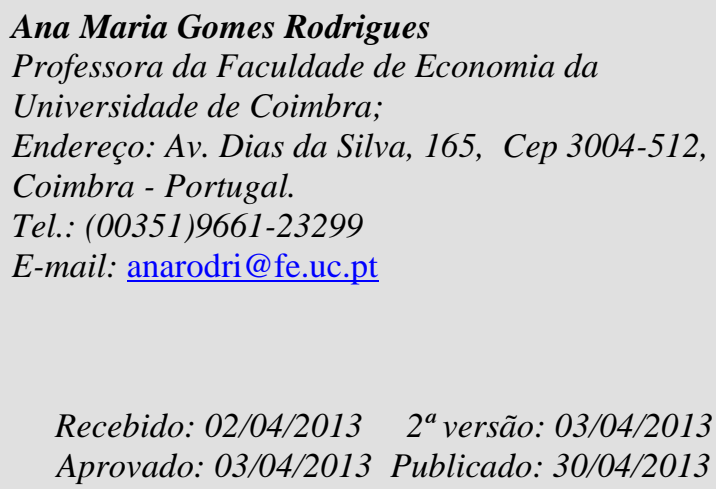

Recebido: 02/04/2013 $2^{a}$ versão: 03/04/2013

Aprovado: 03/04/2013 Publicado: 30/04/2013

\section{RESUMO}

$\mathrm{O}$ artigo versa, numa primeira parte, sobre o conceito de propriedades de investimento. Elencam-se as principais orientações do legislador contabilístico. Posteriormente realiza-se, de modo sumário, uma análise ao seu atual tratamento fiscal. Terminar-se-á com algumas notas conclusivas sobre estas temáticas.

Palavras-chave: Propriedades de investimento; Tratamento contabilístico; Tratamento Fiscal. 
This paper focuses, primarily, on the investment properties concept. We underline the main guidelines followed by the accounting and taxation legislator. An accounting and taxable critical approach will enable us to underline some key and concluding remarks on the topic.

Keywords: Investment properties; Accounting Approach; Tax Law Approach

\section{INTRODUÇÃO}

De entre o amplo conjunto de conceitos indeterminados que hoje dominam a Contabilidade em Portugal $^{2}$, por força da adoção do Sistema de Normalização Contabilística (SNC) e das normas IASB (IAS/IFRS), importa precisar o conceito de propriedade de investimento (PI) ${ }^{3}$. Numa primeira fase, discutiremos este conceito tendo por base as orientações normativas, e analisaremos criticamente a classificação das propriedades de investimento adotada pelo normalizador contabilístico. Numa segunda fase, afloramos de modo muito sumário algumas das questões mais polémicas que esse conceito normativo indeterminado acarreta para a fiscalidade, nomeadamente, no que respeita ao tratamento fiscal das variações do justo valor ocorridas na mensuração subsequente das propriedades de investimentos, bem como os efeitos fiscais da política de reinvestimento dos seus valores de realização. Terminaremos alinhavando algumas notas conclusivas.

\section{PROPRIEDADES DE INVESTIMENTO: UM CONCEITO NORMATIVO?}

\subsection{Propriedades de Investimento: uma discussão do conceito}

Segundo o $\S 5$ da NCRF $11^{4}$, entende-se por propriedade de investimento ${ }^{5}$ a propriedade (terreno ou um edifício, parte de um edifício ou ambos) detida (pelo dono ou pelo locatário numa locação financeira) para obter rendas ou para valorização do capital ou para ambas as finalidades, e não para uso na produção ou fornecimento de bens ou serviços ou para finalidades administrativas, ou, ainda, para venda no curso ordinário do negócio.

A definição de propriedade de investimento, acolhida na NCRF 11, é de natureza complexa. Atende, desde logo, para essa definição ao objetivo da detenção dos imóveis - obter rendas ou para valorização de capital, ou, ainda, para ambas as finalidades - quando a definição devia ser genérica, permitindo determinar apenas o alcance e o sentido imputável à expressão.

A imprecisão do conceito de propriedade de investimento verifica-se, desde logo, quando o legislador em vez de optar por um conceito geral e abstrato aplicável a uma generalidade de situações indistintas se socorre de um conjunto de casos concretos ${ }^{6}$, para densificar esse conceito.

Elencam-se, de seguida, alguns exemplos de propriedades de investimento (cfr. $\S 8$ da NCRF 11):

(a) Terrenos detidos para valorização do capital a longo prazo e não para venda a curto prazo no curso ordinário de negócios;

\footnotetext{
${ }^{1}$ Este artigo representa um complemento ao artigo intitulado "Propriedades de Investimento: Algumas Reflexões Contabilísticas e Fiscais”, publicado na Revista de Finanças Públicas e Direito Fiscal, março, 2012.
} 
(b) Terrenos detidos para um futuro uso correntemente indeterminado (se uma entidade não tiver determinado que usará o terreno como propriedade ocupada pelo dono ou para venda a curto prazo no curso ordinário do negócio, o terreno é considerado como detido para valorização do capital);

(c) Um edifício que seja propriedade da entidade (ou detido pela entidade numa locação financeira) e que seja locado segundo uma ou mais operações de locações operacionais;

(d) Um edifício que esteja desocupado, mas detido para ser locado segundo uma ou mais locações operacionais.

Aquela definição imprecisa é complementada com um conjunto de casos a contrario, ou seja, os imóveis que não devem integrar o conceito de propriedades de investimento, porque o seu proprietário/possuidor determina que as ocupará para desenvolver a sua atividade. Estas são entendidas como as propriedades detidas (pelo dono ou pelo locatário numa locação financeira) para uso na produção ou fornecimento de bens ou serviços ou para finalidades administrativas. Assim, no $\S 9$ da NCRF 11 o normalizador enuncia alguns exemplos de imóveis que não são de classificar como propriedades de investimento:

- Propriedades destinadas à venda no decurso ordinário da atividade comercial ou em vias de construção ou em desenvolvimento com vista à venda (v.g. propriedade adquirida exclusivamente com vista a alienação subsequente num futuro próximo ou para desenvolvimento e revenda). Neste caso concreto, as propriedades estão na alçada da NCRF 18 - Inventários;

- Propriedade que esteja a ser construída ou desenvolvida por conta de terceiros, que é contabilisticamente regulada pela NCRF 19 - Contratos de Construção;

- Propriedade ocupada pelo dono, incluindo, entre outras, as propriedades detidas para futuro uso como propriedade ocupada pelo dono, propriedade ocupada por empregados (paguem ou não os empregados rendas a taxas de mercado), as quais se subsumem às orientações constantes da NCRF 7 - Ativos Fixos Tangíveis.

- Propriedades ocupadas pelo dono aguardando alienação - e, como tal, evidenciadas como ativos não correntes detidos para venda, e reguladas pela NCRF 8 - Ativos não correntes detidos para venda e unidades operacionais descontinuadas.

Importaria que o legislador tivesse elencado claramente nesta disposição ( $\$ 9$ da NCRF 11), que as propriedades ocupadas pelos donos incluíam os imóveis que a entidade utiliza com carácter de permanência para obter rendas, no âmbito da sua atividade principal. Não o fez contudo. Terá aceitado que esta interpretação era exequível, ainda que a contrario, por recurso à definição que adotou para as propriedades de investimento, ou mesmo, por apelo à definição normativa de propriedade ocupada pelo dono?

Para as questões anteriores puderem ser dirimidas, importa apelar à atual definição normativa de propriedade de investimento. Esta, atendendo ao seu objetivo, assenta em dois conceitos fundamentais: a renda e a valorização de capital. A renda deve ser entendida como a retribuição recebida pela cedência do gozo temporário de uma coisa (móvel ou imóvel) ${ }^{7}$. A valorização do capital resulta do acréscimo de valor no imóvel por motivos variados, nomeadamente, boa localização, conjuntura económica, entre outros, mas completamente alheios a qualquer atividade económica concreta desenvolvida pelo seu titular (possuidor/proprietário).

Em nossa opinião, centrar a classificação de um ativo, ou melhor a definição normativa do mesmo, nos fins a atingir com a sua detenção (obtenção de rendas ou valorização do capital) não se afigura suficiente para uma efetiva classificação contabilística dos ativos: importa atender para esse efeito, também, à atividade desenvolvida pela entidade sua possuidora/proprietária, ou seja, ao objeto social da entidade que controla esse ativo e que beneficia da geração dos seus benefícios económicos futuros, pois a renda tanto pode ser obtida no contexto da atividade principal, como fora desse âmbito. Logo, para a 
classificação de um elemento do ativo deve atender-se à sua natureza e, simultaneamente, ao seu destino ou aplicação no âmbito da atividade de uma entidade em concreto. Assim, a função que estes ativos desempenham na entidade não deve, ou não pode, ser ignorada no momento do seu reconhecimento, não podendo colocar-se a tónica apenas no tipo de rendimentos gerados - as rendas, devendo, antes, especificar-se claramente o objetivo da detenção do imóvel relativamente ao objeto social da entidade detentora, pois a natureza das rendas é, em nossa opinião, diversa em função do objeto social da entidade.

Importa perceber, e para efeitos de generalização e abstração do conceito, a duas importantes questões que podem ser equacionadas para a classificação contabilística do imóvel: deve esta classificação depender do objeto social da entidade e da intenção de detenção do referido imóvel? É o tipo de rendimento gerado pelo ativo que deve permitir suportar a classificação contabilística dos imóveis?

É da resposta à primeira destas questões que nos ocuparemos já de seguida. Posteriormente, no ponto 2.1.2 tentaremos responder à segunda questão colocada.

\subsubsection{Classificação dos imóveis atendendo do objeto social da entidade e à intenção da sua detenção}

Socorremo-nos, para o efeito, de uma técnica exemplificativa à semelhança da opção tomada pelo legislador contabilístico. Atenda-se, por isso, a vários exemplos ${ }^{8}$ na mira de precisar essa classificação.

No primeiro admitamos que uma qualquer entidade, que desenvolva a sua atividade fora do sector imobiliário, por exemplo, no sector industrial, apresenta excedentes de tesouraria e decide investi-los na aquisição de um edifício localizado numa região que espera que se valorize, e arrenda essa propriedade por um período longo. Os fluxos de caixa que estes bens venham a gerar são completamente independentes e separáveis dos fluxos das restantes atividades da entidade. Esse imóvel representa, em nosso entendimento, uma propriedade de investimento, uma vez que este foi adquirido com o objectivo de detenção com continuidade ou permanência, para obter rendas e/ou valorização de capital, com fins completamente alheio à atividade principal da entidade. Tal é, também, a opção do legislador contabilístico (alínea c) do $\S 8$ da NCRF 11).

No segundo exemplo, uma entidade explora um qualquer empreendimento, como seja uma barragem, num local afastado da sede da entidade, que implica a deslocação de alguns dos seus empregados para assegurar a atividade principal da entidade. Constroi, junto a esse equipamento, um bairro de habitações que arrenda aos seus empregados. Importa perguntar: como devem ser classificados e reconhecidos contabilisticamente esses imóveis? Em nossa opinião, apenas uma resposta se afigura razoável: estes devem ser reconhecidos como ativos fixos tangíveis (AFT), pois apesar de gerarem rendas, esses imóveis são detidos de modo a permitir desenvolver a atividade integrante do objeto social da entidade, e, logo, esses rendimentos não são independentes dos rendimentos da atividade principal da entidade. Também é esta a solução contabilística plasmada na NCRF 11, cfr. § 9. Neste caso, as propriedades de investimento são indispensáveis para o prosseguimento do objeto societário da entidade.

Admita-se, agora, um terceiro exemplo: uma entidade tem como objeto social ${ }^{9}$ o arrendamento de imóveis. Essa entidade adquire um centro comercial que destina a esse fim. Como deve esse centro comercial ser reconhecido nas contas dessa entidade: como AFT ou como PI? Salvo melhor opinião, esse centro comercial deve ser reconhecido como AFT. Aqui divergimos da solução que parece ser adoptada na NCRF 11. Com efeito, esta norma deixa a solução da contabilização dúbia, à semelhança do disposto na IAS 40.

Para a classificação das propriedades de investimento, deve atender-se à sua particular natureza e função, pois estes bens e direitos caracterizam-se por permanecerem na entidade e gerarem benefícios económicos por períodos longos, não se destinando a ser vendidos ou transformados no decurso normal das operações da entidade, mas podem ser alienados sempre que essa operação se afigure vantajosa ${ }^{10}$, sem 
que essa alienação coloque em causa a continuidade da entidade, pois os fluxos de benefícios económicos que geram são independentes dos fluxos da atividade normal da entidade. Não é, todavia, essa a situação no exemplo anterior, pois nesse caso os benefícios económicos resultantes das rendas dos imóveis devem ser considerados como fluxos operacionais da entidade, já que resultam da sua atividade normal ${ }^{11}$. A interrupção da geração desses benefícios colocará em causa a continuidade da entidade.

$\mathrm{Na}$ generalidade das entidades empresariais, os imóveis para arrendamento (urbanos e rústicos) assumem natureza acessória face ao objeto social dessas entidades, salvo os utilizados para o desenvolvimento da sua atividade administrativa, comercial ou industrial. Entendemos que o investimento em imóveis para arrendamento pode mesmo não caber, salvo disposição expressa nos seus estatutos, no âmbito da capacidade de grande parte dessas sociedades, já que esta compreende «(..) os direitos e as obrigações necessários ou convenientes à prossecução do seu fim, (...)» (n. ${ }^{\circ} 1$ do art. 6. ${ }^{\circ}$ do Código das Sociedades Comerciais (CSC)). As propriedades de investimento podem não constituir direitos necessários à prossecução do fim da entidade, por isso, entendê-las-emos como integrantes da atividade acessória ou colateral da entidade. Defendemos que as sociedades de mediação imobiliária exercem uma atividade económica e, portanto, constituem empresas na aceção do artigo $101 .{ }^{\circ}$ do Tratado sobre o Funcionamento da União Europeia (TFUE). Consequentemente, as PI devem englobar terrenos ou edifícios detidos para obter rendas e ou para valorização de capital, que não estejam afetos à atividade de exploração ou principal, ou ainda, operacional da entidade ${ }^{12} \mathrm{e}$, por isso, os fluxos de caixa destes ativos são independentes dos fluxos de caixa gerados pelos AFT ligados à atividade de exploração ou principal da entidade. Os fluxos gerados pelas PI, neste caso, contribuem em conjunto com os fluxos de caixa gerados pelos ativos operacionais, para o desenvolvimento global da atividade de uma entidade como um todo.

Em nosso entendimento, para uma entidade cuja atividade principal seja a mediação imobiliária, o arrendamento de espaços comerciais, para habitação, ou rústicos, constitui o seu objeto societário, ou seja, a atividade que os sócios se propõem desenvolver com a constituição daquele ente jurídico. São realmente os imóveis os principais ativos que permitem que a entidade desenvolva a sua atividade principal, devendo os mesmos ser classificados como ativos fixos tangíveis (AFT) ${ }^{13}$. In casu, os fluxos de caixa gerados por esses imóveis são os fluxos principais da entidade.

Tanto a norma nacional (NCRF 11), como a internacional (IAS 40), não se revelam claras na classificação das propriedades de investimento, ao colocar a tónica tanto na valorização, como no rendimento gerado (as rendas), sem especificar claramente o objetivo da detenção relativamente ao objeto social da entidade detentora. Essa falta de clareza faz com que o legislador tenha procurado servir-se de exemplos concretos, em detrimento de uma definição geral e abstrata para as referidas propriedades de investimento, o que em muito dificultou a compreensão desta temática.

O nosso organismo normalizador - a Comissão de Normalização Contabilística (CNC) - foi mais longe na tentativa de ultrapasar essa imprecisão conceptual, servindo-se de uma questão concreta que lhe foi colocada, para precisar a classificação das propriedades de investimento.

Na sua FAQ $16^{14}$, e como objetivo de fixar o sentido e eliminar dúvidas que a aplicação do conceito PI constante da NCRF 11 podia suscitar, claramente afirma que "uma entidade que detenha imóveis para rendimento, seja ou não essa a sua principal atividade, deve, no correspondente tratamento contabilístico, observar o disposto na NCRF 11". Assim, o normalizador nacional ${ }^{15}$ basta-se com a condição de detenção do imóvel para rendimento, para claramente defender o seu reconhecimento como propriedade de investimento.

Se a norma nacional e internacional parecia deixar a solução pouco clara, classificando uma propriedade de investimento quando o objetivo da detenção é obter rendas ou valorização de capital, com a emissão daquela FAQ, e pelo menos em termos nacionais, a questão ficou definitivamente esclarecida, ainda que, em nosso parecer, a solução adotada ${ }^{16}$ não seja a mais adequada. Neste esclarecimento da CNC, que pode ser assemelhado a uma norma interpretativa, embora sem valor jurídico reconhecido, parece 
existir uma total indiferença para o normalizador nacional relativamente ao objeto da sociedade locadora, pois admite reconhecer como propriedades de investimento os prédios afetos à atividade principal da entidade, desde que os mesmos sejam arrendados. No caso dos terrenos e edifícios detidos para arrendamento, atende à natureza dos rendimentos gerados, e, também, à intenção da sua detenção pela entidade, ainda que não integre essa intenção no âmbito do objeto social da entidade sua titular

Aliás, interpretando a lei/norma contabilística (nacional e internacional), temos dúvidas que assim tenha que ser. Vejamos, de seguida a nossa fundamentação apelando para o efeito aos tradicionais elementos de interpretação jurídica.

O recurso à interpretação literal não se afigura esclarecedora, pois aí claramente se afirma, $\S 8$ da NCRF $11 a b$ initio, que as propriedades de investimento visam a obtenção de rendas ou a valorização do capital ou ambas as finalidades. Todavia, já a segunda parte do preceito afirma que as propriedades de investimento não são usadas na produção ou fornecimento de bens ou serviços. Importa questionar: será o rendimento gerado por um edifício adquirido para arrendar no âmbito da atividade principal de uma entidade não constitui uma verdadeira prestação de serviços? Em nosso entender, a resposta só pode ser positiva, pois essa é a atividade que os sócios se propõem que a sociedade venha a exercer. Assim, e por recurso à interpretação literal da norma, o conceito de propriedade de investimento permite atender não apenas à natureza dos bens, mas também à concreta função que os mesmos desempenham no âmbito do objeto societário da entidade sua possuidora/proprietária. E essa intenção está claramente explicitada na letra da lei, pois admite o preceito que a propriedade seja detida para valorização ou para a obtenção de rendas, ou para ambos os objetivos. Um imóvel para arrendamento no âmbito da atividade de exploração da entidade não tem nunca como objetivo principal a valorização, mas sim a geração de benefícios económicos futuros no âmbito da sua atividade de exploração, constituindo os mesmos os principais réditos da entidade. Contudo, o conceito de renda adotada pelo legislador contabilístico não nos permite distinguir a renda que resulta do arrendamento de um AFT (rédito) e a que provém de uma propriedade de investimento (rendimento). Se a letra da norma comporta alguma indeterminação, permite, todavia, que apelando à substância económica se possa e deva classificar adequadamente as propriedades (imóveis). Assim, a letra da norma não impede essa classificação mais substancial dos ditos bens, pois o sentido a atribuir-lhe deve ser o que se revelar mais adequado para prosseguir o fim que se quis assegurar com este preceito. A ratio da norma não podia ser aquele que foi acolhido na $F A Q$, atendendo a que o arrendamento de imóveis pode constituir uma verdadeira atividade económica.

O recurso à interpretação sistemática também se afigura de alguma valia, no sentido de decifrar o enigma do reconhecimento inicial dos imóveis, pois em diversas normas do sistema contabilístico se atende às diferentes esferas onde são gerados os fluxos de caixa dos diferentes ativos. Veja-se a importância atribuída às unidades geradoras de caixa no âmbito da NCRF 12 - Imparidade de Ativos, enquanto atividades/subactividades geradoras de diferentes e independentes fluxos de caixa. Os fluxos gerados pelas propriedades de investimento devem ser independentes dos fluxos gerados pelos ativos ligados à atividade de exploração dessa entidade, sendo que os primeiros contribuem em conjunto com os fluxos de caixa gerados pelos ativos operacionais para o desenvolvimento normal da atividade de uma entidade.

A interpretação de natureza sistemática não constitui apoio incondicional à opção do legislador nacional, pois os AFT e as propriedades de investimento integram globalmente a atividade de investimento da entidade, e assim consta da norma-mãe (IAS 40) inspiradora da NCRF 11. Em nome dessa sistemática, houve uma preocupação do legislador de tratar diferentemente a locação dos imóveis (propriedades) das locações contempladas na NCRF 9 - Locação. Assim, se o imóvel se destinar a arrendamento no contexto da atividade de produção ou fornecimento de bens ou serviços, este imóvel deverá ser, em nossa opinião, para efeitos de reconhecimento tratado segundo as disposições previstas na NCRF 7. Outros aspetos do tratamento contabilístico são, contudo, prescritos nessa norma. Assim, em termos sistemáticos, o 
legislador afastou os bens detidos para aluguer no contexto da atividade de fornecimento de serviços do âmbito da NCRF 11, cfr. §§ 4, in fine, e 6 da NCRF 7, ainda que o objeto social da entidade detentora desses bens seja a locação. A opção do legislador na sistemática do quadro de contas e notas de enquadramento, não permite, também, ver claramente a distinção dos imóveis que devem ser classificados como AFT e como PI. Em termos de análise global do sistema contabilístico torna-se claro, em nossa opinião, que as propriedades que são entendidas como propriedades de investimento são, apenas e só, as que não caibam no âmbito do $\S 6$ da NCRF 7. Para esse efeito importa apelar a outras orientações normativas no que a este tema diz respeito. Veja-se, por exemplo, o que refere o normalizador em relação ao reconhecimento dos imóveis como inventários, quando os mesmos se destinam à venda durante o ciclo operacional da entidade, onde claramente se assume para a sua classificação se atende à intenção da entidade sua possuidora. Aqui a atividade principal do proprietário é a venda das propriedades - os inventários são bens detidos para venda no decurso da atividade empresarial e o legislador contabilístico não desconsidera essa atividade na classificação contabilística destes ativos, considerando-os inventários e não propriedades de investimento. Logo, para os terrenos e edifícios detidos para venda a curto prazo no curso ordinário dos negócios, o legislador contabilístico atende não apenas à natureza dos bens, mas, também, ao objetivo da sua detenção, classificando esses imóveis destinados à venda como inventários. Também a respeito dos imóveis classificados como propriedades utilizadas pelo dono o legislador apela à essência económica da operação, ou seja, ao destino que a entidade visa atingir com esses imóveis. Para completar a lista de exemplos, atenda-se ainda à disposição normativa que não prevê a obrigatoriedade de transferência das PI para ativos não correntes detidos para venda, quando a intenção da sua detenção se altere e seja apenas a sua alienação a curto prazo. Na essência desta orientação sobre a não necessidade de transferência das PI para ativos não correntes detidos para venda quanto o seu objetivo de detenção se alterar, e seja agora só a alienação a curto prazo, está implícita a ideia que as PI podem sempre ser alienadas sem que essa alienação constitua verdadeiramente uma alteração do seu fim. Pressupõe-se que estas estão sempre disponíveis para este efeito, logo não se justifica essa necessidade de transferência. Se dúvidas restassem no que a este assunto respeita, bastaria socorrer-nos à disposição que obriga a essa transferência quando os imóveis tenham sido anteriormente classificados como propriedades ocupadas pelo dono e considerados como AFT. Neste último caso, quando a intenção deixa de ser a ocupação pelo dono e passa a ser a sua alienação, o normalizador obriga a uma reclassificação contabilística para atender a esse fim último, visando o seu desreconhecimento a curto prazo, conforme é pressuposto na própria classificação de ativos não correntes detidos para venda. Consequentemente, in causu a entidade desreconhece esses ativos como AFT e passa a reconhecê-los como ativos não correntes detidos para venda. E se se tratar de propriedades de investimento aguardando alienação, não devem estas integrar os ativos não correntes detidos para venda? A norma é omissa a este respeito. Será que esta opção não é justificada pela própria lógica intrínseca subjacente às propriedades de investimento? Entenderá o legislador que as propriedades de investimento não vêm o seu destino afetado pela alienação das mesmas, porque este é, necessariamente, um dos objetivos que lhe está afeto desde o seu reconhecimento inicial? Parece ser esse o entendimento do legislador contabilístico. Consequentemente, entendemos que a interpretação adotada pela CNC na sua FAQ 16, de Junho de 2010, representa um enviesamento no que respeita ao entendimento geral que cabe na IAS 40 e na própria NCRF 11, pois não pode apenas atenderse ao rendimento gerado - rendas - para a classificação dos imóveis como propriedades de investimento ou como ativos fixos tangíveis, sendo necessário apelar a outros critérios para esse efeito.

Também o recurso à interpretação teleológica permite atender aos fins a atingir com esses imóveis no contexto do objeto social da entidade que detém a sua titularidade ou a sua posse, pois as propriedades de investimento visam gerar rendimentos fora da atividade de produção ou do fornecimento de bens ou serviços, $i$. $e$, fora da atividade principal da entidade. Se assim não fosse, não faria qualquer sentido distinguir propriedades de investimento de propriedades ocupadas pelos donos. Apelando à teleologia da NCRF 11, poderemos afirmar que esta não se subsume ao tipo de bens - terrenos e edifícios, pois a ser 
assim não apareceriam os mesmos classificados como inventários, e, também, não apareceria uma subconta especialmente indicada para o mesmo tipo de bens nos AFT, quando os mesmos sejam de considerar como propriedades detidas pelo dono, ou mesmo no âmbito da NCRF 8 sobre os ativos não correntes detidos para venda. A intenção da detenção de um terreno ou de um edifício pode ser diversa e esse entendimento é plenamente integrável no âmbito das normas em análise (NCRF 11 e IAS 40). Enquanto a propriedade de investimento atende à essência económica de aplicação não financeira com carácter de permanência, podendo a mesma ser alienada sem colocar em causa o desenvolvimento futuro da entidade. Todavia, a alienação de um mesmo tipo de imóvel entendido como AFT, poderá colocar em causa a futura geração de benefícios económicos futuros e logo a continuidade dessa entidade, já que, neste último caso, esses imóveis são investimentos que se mostram essenciais para a sociedade desenvolver a atividade subjacente ao seu objeto social.

No $§ 7$ da NCRF 11 adianta-se que "uma propriedade de investimento gera fluxos de caixa altamente independentes dos outros ativos detidos por uma entidade, o que não é o caso quando se trata de propriedades ocupadas pelo dono. Distingue-se por essa razão as propriedades de investimento das propriedades ocupadas pelos donos". O legislador (nacional e internacional) não leva suficientemente longe essa diversidade de fluxos de caixa, pois, em nossa opinião, não basta que esses fluxos sejam só independentes, importaria, simultaneamente, classificar os mesmos atendendo ao tipo de atividade que os gerou, nomeadamente se ocorrem no âmbito do objeto societário integrando a área operacional, ou, se pelo contrário, surgem nas operações de investimento de natureza não financeira.

Justifica-se, pois, perceber a incoerência das disposições normativas, tanto da NCRF 11, como da IAS 40, pois se a atividade principal da entidade for a locação operacional de máquinas, estas são reconhecidas como ativos fixos tangíveis (AFT). Se essa atividade principal for o arrendamento operacional de imóveis não devem estes ter a mesma classificação contabilística que no caso anterior? Fará sentido que neste último caso esses bens devem ser considerados propriedades de investimento e já não ativo fixo tangível? Caberá perguntar qual poderá ser a ratio de tal entendimento?

Por último, como deve ser reconhecido um edifício classificado como hotel para uma determinada entidade que o explora? In casu, o imóvel é detido para a prestação de serviços ${ }^{17}$ aos clientes da entidade. Como deve esse imóvel ser classificado do ponto de vista contabilístico? Em nossa opinião, deve o mesmo ser classificado como AFT e não como propriedade de investimento. É, também, esta a opção do nosso normalizador, seguindo a orientação do IASB. O legislador nacional expressamente ilustra este caso concreto mas, invocando a significância associada aos serviços prestados relativamente às rendas geradas pelo dito imóvel ( $\$ 12$ da NCRF 11). É referido nesse último preceito que se uma entidade possui e administra um hotel, os serviços proporcionados aos hóspedes são significativos para o acordo como um todo. O hotel administrado pelo proprietário é propriedade ocupada pelo dono (AFT) e não propriedade de investimento. Todavia, não é esse o nosso entendimento. Em nossa opinião o hotel é classificado como AFT, porque integra os elementos ativos necessários ao desenvolvimento da atividade principal da entidade, por um período longo, e essa classificação deve ser independentemente do peso representativo dos serviços proporcionados aos hóspedes pela utilização do imóvel. Importa perguntar em que é que o hotel é diferente de um edifício arrendado por uma entidade em que o seu objeto social é o arrendamento de imóveis? Ou porque é que esse hotel é substancialmente diferente da posse e exploração de um centro comercial através do arrendamento das suas frações integrantes? Parece-nos que no espírito do normalizador o hotel só é classificado como AFT porque tem associados outros serviços conexos ao arrendamento propriamente dito do edifício, como sejam as refeições, acesso a equipamentos sociais, limpeza, entre outros serviços que um hotel presta e, simultaneamente, esses serviços são materialmente relevantes. Todavia, será que são esses serviços conexos que fazem com que o arrendamento dos quartos de hotel, permitam classificar o mesmo hotel como uma propriedade de investimento ou uma propriedade ocupada pelo dono? Logo, e só porque os serviços prestados aos hóspedes são significativos é que o legislador optou por classificar este imóvel como AFT e não como $\mathrm{PI}^{18}$. A nossa lógica é diversa, pois o 
hotel deve ser classificado como AFT porque é um ativo detido para prestação de serviços, no caso concreto o arrendamento, que integra a principal atividade da sociedade sua detentora (proprietária ou possuidora), e é essa entidade que assume os riscos e vantagens decorrentes da sua utilização.

O normalizador nacional, à semelhança da opção da norma internacional, optou ${ }^{19}$ por fornecer um conjunto de exemplos muito extenso para efeitos de classificação dos imóveis, entre propriedades de investimento ou propriedades detidas pelo dono. Atendendo a esta técnica legislativa, quando a entidade proporciona vários serviços de apoio aos ocupantes de uma propriedade e associados aos contratos de arrendamento que mantenha, a PI deve ser tratada como "propriedade de investimento" se os serviços forem insignificantes em relação ao acordo como um todo ( 11 da NCRF 11). Este exemplo ilustra bem que um dos critérios definidores de uma PI é a obtenção de rendas, tout court. O exemplo referido no normativo prende-se com o caso de um proprietário de edifício de escritórios, que proporciona, também, serviços de segurança e de manutenção aos arrendatários que ocupam o edifício. Considerando que esses serviços não são significativos, os edifícios são de classificar como propriedades de investimento, segundo o legislador contabilístico. Solução da qual discordamos, pois a classificação devia estar dependente do objeto societário da entidade locadora e não apenas do peso relativo dos serviços acessórios prestados face aos rendimentos da locação do imóvel. Assim, a ratio da classificação centra-se na importância relativa dos serviços de natureza acessória e não na centralidade da sua atividade principal, no caso de esta ser o arrendamento de edifícios.

No $§ 10$ da mesma norma refere que "algumas propriedades compreendem uma parte que é detida para obter rendas ou para valorização de capital e uma outra parte que é detida para uso na produção ou fornecimento de bens ou serviços ou para finalidades administrativas. Se estas partes puderem ser vendidas separadamente (ou locadas separadamente segundo uma locação financeira) ${ }^{20}$, uma entidade contabilizará as partes separadamente. Se as partes não puderem ser vendidas separadamente, a propriedade só é uma propriedade de investimento se uma parte não significativa for detida para uso na produção ou fornecimento de bens ou serviços ou para finalidades administrativas". Esta orientação normativa dá força ao nosso entendimento, permitindo subsumir a classificação contabilística do imóvel à função que este exerce na atividade principal da entidade.

O importante, todavia, era saber o que representa cada um dos contratos de arrendamento na atividade de uma qualquer entidade, pois a afetação permanente dos imóveis a propriedades de investimento deveria conduzir a que estas fossem afetas a fins alheios à atividade principal exercida pela entidade. A norma não distingue, contudo, se essa entidade tem como atividade principal o arrendamento de edifícios e terrenos ou se esses contratos de arrendamento se integram na sua atividade secundária ou colateral.

O legislador socorre-se da essencialidade e da materialidade dos serviços prestados conjuntamente com o arrendamento para a classificação contabilística dos imóveis. Se se atende à materialidade dos serviços conexos, porque não atender ao serviço principal prestado - contrato de locação - que gera rendimentos. Os riscos e as vantagens principais da entidade centram-se no serviço prestado: arrendamento de imóveis.

Os critérios - essencialidade e materialidade - assumem uma natureza secundária, senão mesmo arbitrária e pouco objetiva, em nosso entendimento. Pode ser difícil determinar se os serviços de apoio são ou não tão significativos para que uma propriedade se qualifique como propriedade detida pelo dono ou como propriedade de investimento. Determinar a natureza do investimento (se o imóvel se qualifica ou não como propriedade de investimento) em função dos serviços de apoio fornecidos pelo proprietário/possuidor/detentor serem ou não parte da atividade principal, ainda que apelando à materialidade dos valores, é, no mínimo, discutível e, mesmo injustificável, do nosso ponto de vista para presidir à classificação contabilística de um imóvel, se não se atender simultaneamente ao objeto social da entidade detentora do imóvel, ou seja, ao objetivo da sua detenção para essa entidade em concreto. 
Esta arbitrariedade é assumida pelo legislador nacional, à semelhança do que afirmava o legislador internacional, quando no $\S 14$ da NCRF 11 reconhece que é necessário apelar a juízos de valor para determinar se uma propriedade se qualifica como uma propriedade de investimento ou como uma propriedade ocupada pelo dono. Uma entidade deve, assim, procurar-se munir-se de critérios o mais objetivos possíveis, de modo a que possa exercer esse juízo de valor da forma o mais objetiva e consistente possíveis, atendendo à definição de propriedade de investimento e às orientações previstas nos $\S \S 7$ a 13 da NCRF 11. A alínea c) do $§ 77$ da mesma norma exige que uma entidade divulgue estes critérios quando a classificação se revelar difícil.

Se até junho de 2010, podíamos concluir que legislador internacional, bem como o legislador nacional, tinham deixado pouco esclarecida a questão da classificação dos imóveis, bem como dos rendimentos que estes geravam ${ }^{21}$, o mesmo já não acontece em Portugal depois de a CNC ter emitido a FAQ 16, pois aí o órgão de normalização português optou por uma solução que claramente aponta no sentido da classificação das PI depender mais da natureza do rendimento gerado (as rendas), do que da função que esses imóveis desempenham na atividade da entidade empresarial. Assume-se expressamente nessa FAQ que um imóvel detido, ainda que faça parte da atividade principal ou de exploração de uma entidade, deve ser classificado como uma propriedade de investimento. A solução adotada veio, em nossa opinião, complicar a própria indeterminação do conceito previsto nos normativos. O que antes podia ser entendido como uma omissão ou uma falta de clarificação, hoje, e para o caso português, está perfeitamente clarificado, ainda que, em nossa opinião, não o seja no melhor sentido. Não partilhamos da solução adotada pela CNC.

O $§ 4$ da NCRF 7 claramente afirma que os AFT detidos pela entidade para efeitos de arrendamento devem ser tratados no âmbito da NCRF $9^{22}$, tendo por base a consideração da transferência dos riscos e vantagens associada a esse contrato de locação. Logo, não havia porque provocar esta confusão normativa, quando no ordenamento contabilístico já existia uma norma específica que prescrevia o tratamento contabilístico das locações financeiras e operacionais. Salvo melhor opinião, entendemos que as orientações constantes da NCRF 11 apenas devem ser aplicadas quando os imóveis são verdadeiramente investimentos fora do âmbito da atividade operacional da entidade, e não quando os mesmos são detidos para serem arrendados no âmbito da atividade de exploração de uma qualquer entidade, pois neste caso são, na sua essência, AFT.

Impõe-se agora responder à segunda questão anteriormente formulada, i.e, se será o tipo de rendimento gerado pelo ativo que deve servir de suporte à classificação contabilística dos imóveis. É sobre este temática que nos debruçaremos no ponto seguinte.

\subsubsection{Tratamento contabilístico atendendo ao tipo de rendimento gerado}

O recurso ao conceito de rédito estatuído na NCRF 20 - Rédito ${ }^{23}$, afirma que este é entendido como o rendimento que surge no decurso das atividades ordinárias ${ }^{24}$ de uma entidade, como, por exemplo, vendas, prestação de serviços, juros, dividendos e royalties. A lista apresentada assume natureza meramente exemplificativa.

Poderemos encontrar apoio nesta norma para diferenciar as rendas obtidas das atividades operacionais de uma entidade, das rendas obtidas em outras atividades que não sejam de classificar como de exploração ou operacionais, mas que poderão integrar a atividade de investimento?

Em nossa opinião, o conceito "obter rendas" ou "rendimento de rendas" 25 deve ser reinterpretado de modo a compreender as rendas das propriedades de investimento como não fazendo parte dos rendimentos operacionais da entidade, mas sim dos rendimentos que pertencem à atividade de investimento não financeiro, devendo integrar a categoria de rendimentos de investimentos não 
financeiros. Se a atividade principal da entidade for o arrendamento de imóveis essas rendas constituem, salvo melhor entendimento, a sua prestação de serviços operacionais (conta 72 - Prestação de serviços) e não assumem a natureza de outros rendimento e ganhos (conta 78 - Outros rendimentos e ganhos) ${ }^{26}$, tal como é hoje entendido pelo legislador contabilístico no quadro de contas do SNC. Em nossa opinião, e atendendo à filosofia subjacente a este tipo de rendimentos, as rendas das propriedades de investimento deviam ser classificadas como rendimentos financeiros, devendo integrar a conta 79 - Juros, dividendos e outros rendimentos similares, em obediência à essência económico-financeira subjacente ao investimento. O âmbito da conta 79, considerado pelo nosso legislador, parece demasiado restritivo para integrar as rendas geradas por uma propriedade de investimento. Essas rendas dificilmente são integráveis no âmbito atual dos outros rendimentos similares a juros e dividendos. Também a consideração de uma conta residual 78, com o título "Outros rendimentos e ganhos" de natureza operacional para reconhecer as rendas das propriedades de investimento não foi uma boa opção do legislador contabilístico, pois essas rendas deviam integrar os rendimentos de investimentos não financeiros e não os rendimentos operacionais. Importa atender que se a entidade optar por investir numa aplicação de médio e longo prazo, seja, por exemplo, um depósito a prazo com a duração de três anos, os rendimentos dessa aplicação serão considerados como rendimentos financeiros. Se a opção for da mesma natureza e adquirir um imóvel para obter rendimentos, essas rendas já não são consideradas como rendimentos financeiros pelo legislador contabilístico, pois opta por considerar os mesmos na esfera operacional da entidade quando, na essência, esses rendimentos são, salvo melhor opinião, de natureza financeira. Esta natureza é expressamente assumida na definição de propriedade de investimento, quando define as mesmas como "um terreno ou um edifício (ou parte de um edifício) ou ambos detidos pelo dono ou pelo locatário numa locação financeira, para obter rendas ou para valorização do capital ou para ambas as finalidades, e não para uso na produção ou fornecimento de bens ou serviços ou para finalidades administrativas ou para venda no curso ordinário do negócio". Se a cedência temporária de instalações para arrendamento constituir a atividade principal da entidade (esse imóvel constituirá, em nossa opinião, um AFT), a retribuição (as rendas desses imóveis) representa do ponto de vista contabilístico uma prestação de serviços ${ }^{27}$ dessa entidade (arrendamento operacional), e não já uma renda resultante do arrendamento de uma propriedade de investimento (arrendamento de natureza financeira) ${ }^{28}$.

Os edifícios e os terrenos para uma entidade cuja atividade principal seja a sua locação são, atendendo à sua essência económica, equipamentos básicos (AFT), entendidos como bens detidos com continuidade ou permanência e que não se destinam a ser vendidos ou transformados no decurso normal das operações da entidade. O próprio entendimento de AFT ( $\$ 6$ da NCRF 7) e o conceito de rédito, no caso concreto a prestação de serviço, confirmam esta nossa asserção. Os trabalhos e serviços prestados que sejam próprios dos objetivos ou finalidades principais da entidade são reconhecidos na "conta 72 prestação de serviços". Todavia, o legislador contabilístico ao considerar as PI como investimentos não financeiros, ainda que não integrantes da atividade de exploração da entidade, conduz a que os seus rendimentos também não sejam qualificados como rendimentos de natureza financeira, remetendo-os para os rendimentos operacionais, ainda que de natureza residual. São classificados como outros rendimentos e ganhos.

Segundo o $§ 7$ da NCRF 11, as propriedades de investimento são detidas para obter rendas ou para valorização do capital ou para ambas as finalidades. Por isso, uma propriedade de investimento gera fluxos de caixa altamente independentes dos outros ativos detidos por uma entidade se os imóveis não estiverem afetos aos objetivos ou finalidades principais da entidade. Esta independência dos fluxos gerados deveria permitir distinguir as propriedades de investimento das propriedades ocupadas pelos donos.

A produção ou fornecimento de bens ou serviços (ou o uso de propriedades para finalidades administrativas) gera fluxos de caixa que são atribuíveis não apenas às propriedades, mas também a outros ativos usados no processo de produção ou de fornecimento de serviços. No caso de entidades cuja atividade é a locação de imóveis os outros ativos detidos por essa entidade são meramente secundários ou 
acessórios relativamente aos ativos principais e dos quais resultam os seus réditos - o arrendamento/locação dos terrenos e dos edifícios.

Em nosso entendimento, é premente distinguir o rédito da prestação de serviços resultante do arrendamento de terrenos e imóveis, dos rendimentos gerados pelo arrendamento de terrenos e imóveis que não sejam de classificar como integrantes da atividade de exploração de uma entidade, e que, em essência, devem ser classificados como propriedades de investimento.

Importa, por isso, atender à específica forma de composição dos rendimentos, sendo que as rendas deveriam ser repartidas entre rendimentos de natureza operacional e rendimentos de natureza financeira, pois não fazem parte da atividade principal da entidade, ou seja do seu objeto societário, conforme a função que os imóveis desempenham na entidade que os detêm: AFT ou propriedades de investimento. Socorrer-nos-emos de um exemplo limite para provar o absurdo a que a classificação adotada pelo nosso normalizador, particularmente pós-FAQ 16, pode conduzir. Assim, para uma entidade de mediação imobiliária, cuja atividade principal seja, em exclusivo, o arrendamento de imóveis, quando elabora as suas DF, no seu balanço não figuram AFT, ou no limite figurão em valor muito irrisório, pois os ativos utilizados para desenvolver a sua atividade principal são classificados como propriedades de investimento. In causu, na demonstração dos resultados não serão reconhecidos quaisquer rendimentos de exploração (não figurará qualquer valor em prestação de serviços), apenas aparecerão outros rendimentos e ganhos, que assumem uma natureza residual. E levando a situação de absurdo ainda mais longe, esta entidade não reconhecerá também recebimentos de clientes, figurando os seus principais fluxos de caixa operacionais em outros recebimentos. Será que é esta a intenção do nosso legislador? Esta situação parece-nos paradoxal.

No ponto seguinte iremos elencar outras questões que se prendem, direta ou indiretamente, com as temáticas tratadas anteriormente.

\subsection{Outras questões colocadas pelas opções tomadas pelo legislador contabilístico}

Testar as soluções compreendidas nas normas face às circunstâncias da sua aplicação ao caso concreto é uma forma de assegurar que o seu sentido seja o mais adequado para prosseguir o fim que se quis assegurar com a sua criação, ou seja que a solução que visou consagrar tem relevância para as realidades concretas que visa disciplinar. Se o legislador contabilístico usasse esta metodonomologia na criação das normas contabilísticas certamente esta via conduzi-lo-ia a soluções diversas de muitas das que atualmente estão previstas no sistema contabilístico.

Ainda a este respeito importa atender a uma outra opção legislativa tomada pelo legislador nacional no que respeita às propriedades de investimento no regime da normalização contabilística para as microentidades (NCM), em que acaba por remetê-las para os $\mathrm{AFT}^{29}$. A solução, em nossa opinião, parece não ser a mais acertada, pois reforçou ainda mais a confusão que se tinha instalado a respeito das PI. Em primeiro lugar, em nome da harmonia conceptual que se exige ao sistema contabilístico geral a solução normativa devia ser a mesma qualquer que fosse o subsistema contabilístico em que a entidade se insere. Em segundo lugar, esta opção dificulta a migração das entidades que adotam o NCM para um outro nível da hierarquia contabilística vigente (NCRF - PE; NCRF gerais; ou, ainda, normas do IASB-UE) ${ }^{30}$. Em nossa opinião, esta opção conduz, também, a sérios problemas de comparabilidade entre as entidades integrantes nos diferentes níveis de hierarquia do sistema contabilístico atual. Entendemos que outra devia e podia ter sido a solução adotada pelo normalizador, em nome da coerência do sistema geral. Por último, esta classificação adotada na NCM conduz a uma falta de harmonia no sistema contabilístico ${ }^{31}$. 
Pensamos que, no caso das propriedades de investimento e nas propriedades detidas pelo dono, perdemos clareza em relação às disposições do anterior normativo contabilístico - o POC - pois aí objetivamente se assumia que os imóveis detidos com objetivos de arrendamento faziam parte dos investimentos financeiros. Os utilizados para desenvolver a atividade normal da entidade eram registados como imobilizado corpóreo. Estes ativos integravam o conceito de equipamentos básicos, que compreendia o conjunto de bens que permitiam a prestação de serviços que era objeto da atividade da entidade.

Tal como se referia no ponto 2.1 do Capítulo 2 - Considerações técnicas, do POC, com a adoção da $4^{\text {a }}$ Diretiva, os elementos do ativos passaram a ser classificados não atendendo exclusivamente à sua natureza, mas também ao seu destino ou aplicação. Esta alteração teve consequências não despiciendas, nomeadamente, na classificação dos investimentos financeiros, como seja o caso dos prédios de rendimento, que deixaram de figurar no imobilizado corpóreo e passaram a integrar os investimentos financeiros. A conta de Investimentos financeiros (conta 41) incluía uma subconta designada de investimentos em imóveis - que englobava as edificações urbanas e propriedades rústicas que não estivessem afetas à atividade operacional das empresas.

Referia-se no POC que as imobilizações corpóreas integravam "os elementos tangíveis, móveis ou imóveis, que a empresa utiliza na sua atividade operacional, que não se destinem a ser vendidos ou transformados, com carácter de permanência superior a um ano". Os terrenos e os recursos naturais reconhecidos nas imobilizações corpóreas compreendiam "os terrenos e recursos naturais (plantações de natureza permanente, minas, pedreiras, etc.) afetos às atividades operacionais da empresa". Logo, se esses edifícios estivessem afetos a essas atividades deviam ser entendidos como equipamentos básicos, que, conforme referimos antes, compreendiam o conjunto de bens que permitiam à entidade realizar a prestação de serviços que era objeto da sua atividade (arrendamento dos espaços com vista a obter réditos de prestação de serviços).

Segundo o $§ 6$ da NCRF 7 considera-se que constituem elementos fixos tangíveis, os detidos para utilização na produção ou fornecimento de produtos ou serviços, os bens detidos para arrendar a terceiros, e os utilizados para fins administrativos, que se espera que sejam usados durante mais do que um período na entidade. Consequentemente, os imóveis afetos à atividade principal da entidade deviam ser classificados como ativo fixo tangível, segundo o que se dispõe na própria NCRF 7. Contudo, quando se trata de distinguir entre a atividade principal (arrendamento de edifícios), ou o arrendamento que representa uma mera atividade a título acessório ou complementar (arrendamento de edifícios), será que se pode omitir a função que esses mesmos investimentos têm na entidade?

Em nome da unidade do sistema contabilístico fará sentido a solução normativa constante da NCRF 11, principalmente depois da publicação da FAQ 16 ?

Dir-se-á que a NCRF 11 e a IAS 40 não resolvem este aspeto concreto dada a natureza técnica e especializada da questão. Os ativos fixos tangíveis são usados pelas entidades, como recursos, para o desenvolvimento dos negócios que cabem no âmbito da sua capacidade. Na interpretação do texto da lei, que fizemos ao longo do ponto 2.1.1, concluimos que ainda que a sua letra e sistemática sejam invulgares ou inusuais, ainda assim não contrariavam uma classificação mais adequada para a classificação dos imóveis, bastando para tal atender ao primado da substância sobre a forma, previsto no ordenamento contabilístico como requisito da fiabilidade da informação financeira.

A questão da classificação de um imóvel como ativo fixo tangível ou como propriedade de investimento não é de somenos importância, dado o diferente tratamento contabilístico adotado pelo legislador contabilístico na mensuração subsequente de cada um desse tipo de ativos ${ }^{32}$. A inevitável álea subjacente a esta questão tem fortes implicações sobre a informação divulgada nas DF preparadas de acordo com o padrão contabilístico vigente (SNC ou IASB-UE). 
O normalizador admite como modelo de mensuração subsequente para as $\mathrm{PI}^{33}$ o modelo do justo valor, sempre que se afigure razoável conhecer com fiabilidade esse justo valor das PI. A opção por este modelo conduz ao reconhecimento das variações, positivas ou negativas, do justo valor nos resultados do período. Todavia, a mesma norma (NCRF 11) admite a mensuração subsequente custo depreciado menos quaisquer perdas por imparidade sempre que a determinação do justo valor não se revele suficientemente confiável. Neste último caso, o legislador remete para a mensuração subsequente para a NCRF 7 (IAS 16). Todavia, se o imóvel for considerado AFT os modelos admissíveis na mensuração subsequente são: modelo da revalorização ou o modelo do custo, em função da fiabilidade ou não da determinação do justo valor. Ainda que admita esta duplicidade possível na mensuração subsequente, quando se trata de reconhecer os acréscimos da revalorização, vem a considerá-los como excedentes de revalorização (conta 58) e entende-os como variações nos capitais próprios. Fácil é entender que as entidades podem preferir adotar o modelo do justo valor já que as suas variações são reconhecidas diretamente em resultados. Todavia, essa solução só será favorável para os indicadores de desempenho quando se está em período de valorização dos imóveis. Sendo, contudo, altamente penalizante em situações de crise como aquela que vivemos atualmente em Portugal.

Esta dupla opção normativa na mensuração subsequente e o tratamento diferenciado em resultado do modelo de mensuração subsequente adotado pode ser um dos grandes responsáveis pela indeterminação presente na NCRF 11 (IAS 40), pois à data de criação destas normas ainda o mundo vivia numa situação de euforia de crescimento dos preços dos imóveis.

Se o órgão normalizador tivesse atendido ao objeto social das entidades detentoras dos imóveis, dificilmente, e em nome da coerência do sistema, teria vindo a considerar todas as variações do justo valor como rendimentos do período. Para as PI que são arrendadas e que constituem rendimentos normais da entidade certamente essas variações de justo valor não podiam e deviam concorrer para os resultados do período, pois não é previsível a sua venda a curto prazo. Teria optado, neste caso, pelo modelo da revalorização à semelhança da opção tomada para os AFT, por reconhecer que esses ativos não poderão ser alienados de forma "quase livre" sem condicionar toda a geração de benefícios económicos resultantes da atividade normal da entidade, a sua sobrevivência e continuação no mercado. Apenas a hipótese da disponibilidade quase imediata dos referidos ativos, apesar de não serem classificados ativos não correntes detidos para venda, pode justificar a opção pelo modelo do justo valor, numa perspetiva tão lata. Ainda assim e, mesmo admitindo a disponibilidade imediata das PI para venda, ou seja de as mesmas serem detidas com a finalidade de alienação, temos dificuldades em aceitar que as variações do justo valor possam ser consideradas rendimentos do período, já que há um risco significativo de alteações de valor neste tipo de ativos. Discordamos, em qualquer caso, que as variações de justo valor em ativos não correntes possam afetar os resultados do período contabilístico em que as mesmas tiveram lugar ${ }^{34}$. Consequentemente sejam as PI verdadeiramente propriedades de investimento ou AFT na nossa perspetiva, a conclusão vai no sentido de não se adotar o modelo de justo valor na mensuração subsequente em qualquer dos casos, defendendo nós que o modelo a adotar deva ser o modelo de revalorização.

A imprecisão do conceito condiciona, necessariamente, o tratamento contabilístico posterior ao reconhecimento inicial (mensuração subsequente). Podemos encontrar amparo para esta leitura na NCRF 8, pois as PI são o único caso em que o legislador contabilístico se abstém de obrigar à sua transferência para ativos não correntes detidos para venda, aquando da decisão da sua futura alienação. Omissão do legislador? $\mathrm{Ou}$, apenas, considerou que as propriedades de investimento não vêm o seu destino afetado pela provável alienação das mesmas, por este ser, necessariamente, um dos objetivos que lhe está afeto desde o seu reconhecimento inicial, conforme tivemos oportunidade de referir anteriormente.

De seguida passaremos em revista, ainda que de modo necessariamente sumário, o tratamento fiscal previsto para as propriedades de investimento, particularmente, no que respeita à mensuração 
subsequente, dada a alternatividade de modelos previstos pelo legislador contabilístico (modelo do custo versus modelo do justo valor).

\section{OS REFLEXOS FISCAIS RESULTANTES DA IMPRECISÃO DO CONCEITO NORMATIVO DE PROPRIEDADES DE INVESTIMENTO ${ }^{35}$}

É comummente aceite que a determinação do lucro tributável assenta numa relação de dependência parcial relativamente à Contabilidade. Na recente adaptação, em 2010, do CIRC aos novos normativos contabilísticos (normas IASB-UE e SNC) houve uma clara opção pela manutenção do modelo de dependência parcial do Direito Fiscal relativamente à Contabilidade, o qual determina, quando não estejam estabelecidas regras fiscais próprias, o acolhimento do legislador é a que resultar do tratamento contabilístico decorrente dos novos referenciais contabilísticos. A lei fiscal pode desviar-se das regras contabilísticas, ainda que em termos excecionais, quando a contabilidade não acautela adequadamente o interesse fiscal. A contabilidade e o direito fiscal têm interesses distintos, mas ainda assim o «casamento» entre estas duas áreas dogmáticas é evidente, sendo que o legislador fiscal utiliza frequentemente termos e conceitos de natureza puramente contabilística. Sempre que a obtenção de receitas públicas é posta em causa, o legislador fiscal pode não acompanhar, total ou parcialmente, as orientações contabilísticas, devendo para o efeito pronunciar claramente sobre esse afastamento. Deve atender-se que as orientações ditadas pelo normalizador contabilístico visam essencialmente atender aos objetivos de prestar informação mais relevante para os destinatários da informação financeira, sem atender a quaisquer preocupações de natureza fiscal. Assim, a lei fiscal consente e impõe pontuais alterações às disposições do legislador contabilístico, ainda que pressupondo sempre uma prévia regra fiscal legitimadora, através de lei ou decreto-lei autorizado.

Elencam-se, de seguida, as principais implicações fiscais resultantes das atuais perplexidades do conceito de propriedades de investimento adotado em termos contabilísticos e estas são, essencialmente, de dois tipos. A não consideração das variações de justo valor como relevantes para o apuramento do lucro tributável e a política de reinvestimento admitida pelo legislador fiscal. Consequentemente, são estas questões que se assumem como críticas na fiscalidade em resultado da imprecisão do conceito de PI.

No primeiro caso, relativo às variações do justo valor, o legislador fiscal opta por não admitir que estas concorram para o lucro tributável. Também o não faz para os outros ativos tangíveis, e intangíveis, casos em que as variações do justo valor são reconhecidas como capitais próprios, em excedentes de revalorização, concorrendo para o lucro tributável as diminuições, mas não os aumentos que são expressamente afastados, cfr. n. $^{\circ} 9$ do art. $18 .^{\circ}$ do CIRC. Assim, e para o caso das PI, e pelo carácter de dispensabilidade que lhe devia assistir, estamos convictos da boa decisão do legislador fiscal.

No segundo caso, prevê um tratamento vantajoso ao considerar fiscalmente o reinvestimento dos valores de realização obtidos na alienação das propriedades de investimento, tributando, em consequência, apenas $50 \%$ do saldo positivo das mais-valias e menos-valias realizadas mediante a transmissão onerosa deste tipo de ativos.

Neste particular, o legislador fiscal optou por aceitar o reinvestimento dos valores de realização, quando os imóveis sejam classificados como PI de exploração à semelhança da solução adotada para os ativos fixos tangíveis. O legislador fiscal admitiu o reinvestimento desde que as referidas PI estejam afetas aos objetivos e finalidades principais da entidade - as PI de exploração. Mais uma vez a questão revela-se complexa, pois se os imóveis forem afetos à exploração, em nossa opinião, devem ser considerados como propriedades detidas pelos donos, ou seja, AFT e não PI. Todavia, a letra da lei físcal é pouco clara, sendo que o legislador refere que os ativos não correntes a que o reinvestimento se pode aplicar devem estar ligados à exploração, e entre eles elenca as propriedades de investimento. Atrás fizemos referência à 
confusão a que a NCRF 11 pode conduzir, no que respeita à classificação e reconhecimento dos imóveis, pois torna-se claro do ponto de vista contabilístico, pelo menos em Portugal depois da FAQ de Junho de 2010, que os imóveis para rendimento são sempre reconhecidas como PI. Importa, em nossa opinião, desconsiderar a referida FAQ, até pelo não atribuição de valor jurídico que esta assume, e reconhecer as PI afetas à exploração normal como AFT, remetendo para o verdadeiro conceito de PI os imóveis detidos que não se relacionam com a atividade principal da entidade. Esta clarificação de conceitos impõe-se em nome de um princípio caro à teoria contabilística: o primado da substância sobre a forma. Outra solução diversa, mas que conduziria ao mesmo resultado passaria pelo legislador contabilístico classificar todos os imóveis como PI, reclassificando-as em seguida como PI de investimento e PI de exploração. Parece ter sido este o entendimento do legislador fiscal. Todavia, esta última opção casa mal com a letra do normativo contabilístico, pois se assim o entendesse não havia porque considerar na NCRF 11 as propriedades ocupadas pelo dono, ainda que neste caso estas passassem a estar incluídas nas PI de exploração.

Em nosso entender, a opção fiscal é injustificável e até perplexa se contemplar o conceito de PI adotado pelo legislador contabilístico. Todavia, entendemos o mesmo como uma boa opção do ponto de vista fiscal se o reinvestimento para efeitos fiscais só for aceite para as PI, que na essência não são verdadeiras propriedades de investimento, mas AFT. A indefinição do normalizador contabilístico pode dar azo a confusões, pois o legislador fiscal criou um novo conceito de PI de exploração, sem o definir adequadamente, não se demarcando do conceito contabilístico. Esta situação é particularmente gravosa quando entendemos que o afastamento do legislador fiscal em relação ao disposto no normativo contabilístico pressupõe uma prévia regra fiscal legitimadora, com a natureza de lei ou decreto-lei autorizado $^{36}$. Assim, no futuro esta situação poderá conduzir a conflitualidade significativa entre a Administração Tributária e os contribuintes. Quando se tratar de decidir o que se deve entender por propriedades de investimento de exploração como deve a doutrina e a jurisprudência densificar esse conceito? O legislador contabilístico apenas avança com um conceito de PI, que na sua essência transporta imensas dúvidas e perplexidades.

Assumindo-se o regime de reinvestimento como estrutural, pois está inerente à própria estrutura do imposto, o reinvestimento ${ }^{37}$ representa um verdadeiro regime especial de desagravamento. Por esse fato, a natureza estrutural do preceito fiscal do reinvestimento devia incentivar a atividade económica, visando apoiar, no essencial, a atividade integrante do objeto societário e não meras aplicações que revelam natureza financeira para as entidades cuja atividade é estranha ao seu objeto societário. Pensamos que, para o caso dos imóveis que visam apenas complementar a atividade principal da entidade, pode não se justificar esse desagravamento fiscal, até porque em termos de política fiscal se desconsidera o mesmo até para outros ativos ligados à exploração, nomeadamente, para os ativos intangíveis ${ }^{38}$.

Permitimo-nos olhar com desconfiança para essa disposição legal se for aplicada às PI tal como hoje são entendidas na Contabilidade, pois entendemos que alargar esta vantagem fiscal ao reinvestimento das propriedades de investimento quando estas, em essência, podem não fazer parte da atividade operacional da entidade ( $\S \S 5$ e 9 da NCRF 11), assumindo-se esse tipo de investimento muitas vezes estranho ao objeto societário é de utilidade duvidosa ${ }^{39}$, enquanto verdadeiro desagravamento fiscal estrutural. Entendemos, no entanto, que a ratio legis do preceito fiscal é outra e que o legislador fiscal quer apenas conceder esse verdadeiro benefício fiscal às PI que sejam na sua essência AFT, fugindo, assim, à definição pouco clara do legislador contabilístico. Todavia, importaria, em nome da justiça fiscal e do evitamento de conflitos, que tivesse sido claro no entendimento que adotou de PI, admitindo que este seja diferente do acolhido pela Contabilidade, devendo, por isso, o legislador fiscal ter optado por definir o referido conceito.

Depois das incoerências elencadas ao longo deste trabalho, pensamos que o legislador contabilístico, deve procurar esclarecer o conceito de PI, assegurando deste modo que a função informativa da Contabilidade seja integralmente cumprida, e, simultaneamente evitando que outras áreas 
dogmáticas intimamente ligadas à Contabilidade, como é o caso do Direito Fiscal, incorporem essas indefinições no seu seio, evitando futuras situações de conflitualidade.

\section{NÓTULAS CONCLUSIVAS}

Qualquer solução normativa não é pacífica quando existem dúvidas e divergências na sua interpretação. Assim, e porque a NCRF 11 se integra nesta categoria, deixando a classificação e o reconhecimento das PI pouco claro, o legislador contabilístico nacional pretendeu ultrapassar posteriormente essas peias. Todavia, nessa sua tentativa acabou por introduzir, mediante a publicação de uma FAQ, uma complicação adicional na indeterminação constante da própria norma (NCRF 11), ao admitir que as PI podem incluir os imóveis destinados à obtenção de rendimentos, seja ou não essa a principal atividade da entidade sua proprietária/possuidora.

Eem nosso entendimento importaria, todavia, uma adequada classificação contabilística dos imóveis detidos por uma entidade. Assim, duas situações importariam reter para este efeito: na primeira, a locação do imóvel constitui o objeto de negócio da entidade, ou seja integra a sua atividade operacional ou normal, como é o caso dos imóveis detidos por uma sociedade de mediação imobiliária, e neste caso os mesmos deveriam ser classificado como AFT. Assim, um imóvel arrendado deve, em nossa opinião, ser reconhecido como ativo fixo tangível, quando o seu arrendamento se assumir como a atividade principal da entidade, constituindo esse ativo a base para a prestação dos serviços principais da entidade, ou por, simultaneamente, esse imóvel estar ligado a um qualquer outro AFT, assumindo-se como complementar na produção ou fornecimento de bens e serviços. Em ambos os casos, esses ativos geram os principais fluxos de caixa da entidade Outra situação diversa é quando a atividade de locação representa uma mera atividade secundária, acessória ou colateral na entidade possuidora dos imóveis. Estes são detidos, in casu, com vista a rendibilizar esse investimento, cujo objetivo é meramente de natureza financeira. Nesta circunstância esse ativo é mantido com o principal objetivo de valorização ou obtenção de rendas, não fazendo parte da atividade principal, devendo, por isso, ser considerado como propriedade de investimento. Neste caso, as PI produzem um fluxo de caixa independente dos fluxos gerados pelos outros ativos detidos pela entidade, constituindo um ativo secundário/acessório relativamente aos ativos afectos à atividade principal desenvolvida pela concreta entidade, que poderá vir a ser desreconhecido sem afectar a atividade principal da entidade através da obtenção de rendimentos resultantes de rendas ou da mera valorização da propriedade.

A nossa lógica é postergada, ainda que indiretamente, pela própria norma, quando esta obriga à classificação dos imóveis como inventários, cf. disposto na alínea a) do $§ 9$ da NCRF 11, sempre que a propriedade adquirida se destine exclusivamente à alienação subsequente num futuro próximo ou para desenvolvimento e revenda.

Tendo em conta toda a análise desenvolvida, podemos concluir que não faz sentido que se utilizem lógicas diversas dentro do mesmo sistema contabilístico, sob pena de violar a harmonia interna do próprio sistema. Consequentemente, o normativo contabilístico em algumas das situações atende ao objetivo da detenção dos imóveis e em outras desconsidera-as em absoluto.

O legislador contabilístico não se pautou, até agora, pelo realismo e transparência no que às PI diz respeito. Os desentendimentos na esfera contabilística relativas ao conceito de propriedade de investimento são diversos, fazendo com que a principal função da Contabilidade - a função informativa possa estar comprometida, para além de poder conduzir a discórdias entre áreas dogmáticas próximas, ainda que com objetivos diversos, como é o caso da contabilidade e da fiscalidade. A imprecisão do conceito cria, assim, as condições ideais para o surgimento de conflitos, pois o entendimento do legislador contabilístico é depois vertido em disposições fiscais que também não se afiguram claras. 
Tendo em conta as incoerências elencadas ao longo deste trabalho, o legislador contabilístico devia procurar assumir um conceito suficientemente claro para a questão em análise, privilegiando a essência económica das propriedades de investimento, e usando como critério de classificação deste ativo a natureza, a intenção e a função que o mesmo desempenha, atendendo às atividades que os sócios propõem que a sociedade venha a exercer e que constituem o seu objeto social.

Neste âmbito importará que no futuro o normalizador venha a suprimir as indefinições e, ultrapassar as suas enormes vicissitudes do conceito em nome da lógica e unidade do sistema jurídicocontabilístico, que se pretende coerente e transparente.

2 Importa referir que esta não é uma situação específica do caso português. Também no Brasil se verifica o mesmo fenómeno por força da adoção do normativo internacional, bem como na generalidade dos países que adotaram as normas internacionais de contabilidade, que se baseiam, no esencial, no paradigma anglo-saxónico. Assim a generalidade das apreciações que fazemos relativamente às implicações contabilísticas para o caso português, aplicam-se ipis verbis ao caso brasileiro.

3 Utilizaremos ao longo deste trabalho, indiferentemente, Propriedades de Investimento ou apenas PI.

4 Ao longo do texto analisaremos, essencialmente, norma portuguesa: a NCRF 11 - Propriedades de Investimento, dada a quase coincidência da mesma com a IAS 40, com a mesma epígrafe. Também, no Brasil o CPC 28 - Propriedade para Investimento é concordante com a norma internacional, pelo que o que as conclusões obtidas neste trabalho para o caso português podem ser transpostas para o caso brasileiro, dada a identidade de situações.

Todos os negritos utilizados ao longo do texto, sem qualquer referência adicional, foram utilizados por nós com o objetivo de dar realce.

${ }^{6}$ Utiliza esta técnica exemplificativa ao longo de toda a NCRF 11.

${ }^{7}$ Conforme arts. $1022 .^{\circ}$ e ss. do Código Civil. Centraremos a nossa análise nos prédios rústicos e urbanos e nas partes integrantes desses prédios.

${ }^{8}$ Outros exemplos podem ser consultados em Rodrigues et al. (2010: 523 e ss.)

9 No n. ${ }^{\circ} 2$ do art. 11. ${ }^{\circ}$ do CSC pode ler-se: “como objeto da sociedade devem ser indicadas no contrato as atividades que os sócios propõem que a sociedade venha a exercer”. O n. 3 afirma que "compete aos sócios deliberar sobre as atividades compreendidas no objeto contratual que a sociedade efetivamente exercerá, bem como sobre a suspensão ou cessação de uma atividade que venha ser exercida".

${ }^{10}$ Deve atender-se às eventuais "penalidades civis", através do instituto da indemnização, que podem vir a ocorrer se a entidade tiver celebrado um contrato de arrendamento e tiver necessidade de resolver ou denunciar esse contrato no prazo previamente fixado.

11 A atividade normal é aqui entendida como a atividade principal da entidade.

12 Vasconcelos (2011: 200) pronuncia-se no mesmo sentido.

${ }^{13}$ E neste caso devem ser contabilizados de acordo com a NCRF 9 - Locações, sendo de classificar, por regra, esses contratos como "contratos de locação operacional", tendo em conta os riscos e vantagens inerentes a este tipo de locação. Ver § 4, in fine, da NCRF 7.

${ }^{14}$ Refere-se no site da CNC que "com vista a contribuir para a melhor aplicação do Sistema de Normalização Contabilística, a CNC entendeu divulgar um conjunto que questões que lhe têm sido recorrentemente apresentadas e que, pela sua importância, considera que são merecedoras de divulgação. Naturalmente que as respostas originais foram emitidas em relação a questões concretas descritas nos pedidos endereçados à CNC. Porém, e para divulgação nesta página, tais respostas foram objeto de adaptação a fim de garantir a necessária protecção de dados ou informações que, aliás, em nada acrescentariam à compreensão técnica das matérias. Por último, anote-se que as respostas a consultas aqui divulgadas, devem ser apreciadas tendo em conta a data em que foram produzidas e que as mesmas têm um carácter meramente informativo, não constituindo, em caso algum, um acto administrativo".

15 Importa atender que o órgão responsável pela interpretação é o mesmo que elaborou a norma interpretada (a NCRF 11), ainda, que num papel distinto, pois as FAQ não se assumem como normas de valor hierárquico equivalente à norma interpretada, constituindo meras notas informativas, sem qualquer valor jurídico vinculativo associado. 
${ }^{16}$ A interpretação constante da FAQ é a prova cabal da falta de clareza do conceito de propriedades de investimento adotada pelo nosso normalizador, à semelhança do seu congénere internacional.

${ }^{17}$ Segundo o $\S 4$ da NCRF 11 "a prestação de serviços envolve tipicamente o desempenho por uma entidade de uma tarefa contratualmente acordada durante um período de tempo acordado. Os serviços podem ser prestados dentro de um período único ou durante mais do que um período".

18 Importa apresentar um contra-exemplo para perceber as diferenças essenciais de classificação: imagine-se que uma entidade de mediação imobiliária é detentora de um palacete, e resolve transformar o referido edifício num espaço destinado a turismo rural. Não presta qualquer outro serviço associado além do arrendamento do espaço e os serviços de limpeza. Como deve esse edifício ser classificado? Para o normalizador nacional esse edifício será uma propriedade de investimento. Em nossa opinião esse edifício deve ser entendido como um AFT.

${ }^{19}$ Esta é talvez a norma onde o apelo a exemplos para efeitos de clarificação de uma classificação contabilística é levada mais longe, o que de algum modo permite aferir que o próprio legislador tinha a convicção da dificuldade associada à classificação de propriedades de investimento versus propriedades detidas pelo dono.

${ }^{20}$ Agora a ratio vai para a natureza do contrato - de compra e venda ou de locação financeira. E se for uma locação operacional? Porquê apelar para o contrato de compra e venda e não para a dependência/independência dos fluxos de caixa gerados?

21 Esta é uma área onde existem divergências conceituais significativas. Ver sobre o assunto a resposta integrante nas perguntas frequentes sobre o SNC, as designadas FAQ, da Comissão de Normalização Contabilística (CNC) e, na doutrina, Rodrigues (2012b) e Rodrigues et al. (2011c). Em nosso entender, para uma sociedade de mediação imobiliária, cujo objeto social compreenda o arrendamento de prédios, a entidade deve reconhecer estes imóveis como ativo fixo tangível Equipamento básico, e não em propriedades de investimento. Todavia, outro é o entendimento da CNC na sua FAQ 16.

${ }^{22}$ No $\$ 4$ da NCRF 7 afirma-se que "outras Normas podem exigir o reconhecimento de um item do ativo fixo tangível com base numa abordagem diferente da usada nesta Norma. Por exemplo, a NCRF 9 - Locações exige que uma entidade avalie o seu reconhecimento de um item do ativo fixo tangível locado na base da transferência de riscos e vantagens. Porém, em tais casos, outros aspectos do tratamento contabilístico para estes ativos, incluindo a depreciação, são prescritos por esta Norma".

${ }^{23}$ Inspirada na IAS 18 .

${ }^{24} \mathrm{O}$ conceito de atividade ordinária (ou corrente) é hoje bastante lato, envolvendo a atividade operacional, e uma boa parte das atividades que não devam ser classificadas de investimento ou financeiras, pois desde a entrada em vigor das normas do IASB-UE e do SNC o conceito de atividade extraordinária foi abandonado, reconduzindo-se, hoje, os rendimentos de uma entidade à atividade operacional, financeira ou de investimento.

${ }^{25}$ Expressão que o legislador contabilístico se socorre no ponto ii) da alínea e) do $\S 77$ da NCRF 11.

${ }^{26}$ O legislador optou, todavia, por considerar as rendas globalmente na conta geral 78 - Outros rendimentos e ganhos, mais precisamente em rendimentos e ganhos em investimentos não financeiros (subconta 787), optando por criar uma subconta 7873 com o título de "outros rendimentos em propriedades de investimento".

27 Ver $\$ 4$ da NCRF 20.

${ }^{28}$ Deve atender-se que o arrendamento com carácter financeiro que referimos não é o arrendamento financeiro subjacente à NCRF 9, optando-se por essa terminologia apenas para efeitos de o distinguir do arrendamento enquanto atividade principal da entidade, entendida como prestação de serviços. Uma locação financeira, à luz da NCRF 9, deve ser entendida como aquela que transfere substancialmente todos os riscos e vantagens inerentes à posse de um ativo. O título de propriedade pode ou não ser eventualmente transferido. Não é esse, contudo, o âmbito que considerámos neste trabalho, já que a nossa análise das locações das propriedades de investimento cinge-se às locações operacionais e não financeiras.

${ }^{29}$ Dispõe o ponto 7.2 da NCM - Norma Contabilística para microentidades - que "[a]s designadas propriedades de investimento (terrenos e edifícios), bem como os ativos biológicos de produção, são reconhecidos como ativos fixos tangíveis", independentemente da função que os mesmos desempenhem na entidade.

${ }^{30}$ Prevê-se no preâmbulo da Lei n. ${ }^{\circ} 36-\mathrm{A} / 2011$, de 9 de Março que a metodologia adoptada permite uma fácil comunicabilidade vertical sempre que alterações na dimensão das entidades visadas 
impliquem diferentes exigências de relato financeiro ou as entidades exerçam a opção pela aplicação das normas contabilísticas gerais, contidas no Decreto-Lei n. ${ }^{\circ}$ 158/2009, de 13 de Julho, tal como previsto no art. 5. ${ }^{\circ}$ da Lei n. ${ }^{\circ} 35 / 2010$, de 2 de Setembro.

${ }^{31}$ Esta opção pode conduzir não apenas a problemas de comparatibilidade entre entidades contabilísticas que utilizam diferentes normativos contabilístico, dentro do quadro contabilístico nacional, mas também a problemas fiscais, nomeadamente no não reconhecimento das perdas por imparidade para os AFT no âmbito da norma das microentidades, tão-somente porque na NCM o legislador abandonou o conceito de imparidade. Assim, e mesmo que venham a ocorrer diferenças entre o valor escriturado e o valor de uso ou o valor de venda para estes ativos não se admite o reconhecimento de perdas por imparidade.

${ }^{32}$ Sobre os fatores que influenciam na decisão entre valor justo e modelo do custo, ver Batista et al. (2012). Sobre a aplicabilidade de cada um desses modelos às PI ver: Rodrigues (2012b).

33 Para uma análise mais desenvolvida, ver Rodrigues (2012b).

${ }^{34}$ Para uma análise mais desenvolvida, ver Rodrigues (2011a).

${ }^{35}$ Este ponto do nosso trabalho visa apenas analisar os reflexos fiscais resultantes da imprecisão do conceito normativo de propriedades de investimento em Portugal, pois, lamentavelmente, desconhecemos o entendimento do legislador brasileiro a este respeito.

${ }^{36}$ Ver sobre estas questões Nabais (2010) e Saldanha Sanches (1995 e 2007).

${ }^{37}$ Por isso, entendemos não tratar o reinvestimento dos valores de realização como um verdadeiro benefício fiscal, já que estes apresentam um carácter temporário, e variam em função de objetivos conjunturais de política económica.

${ }^{38}$ Opção fiscal que entendemos discutível. Ver a propósito Rodrigues (2011b).

${ }^{39}$ Sobre a desigualdade de oportunidades fiscais ao reinvestimento, ver Rodrigues (2011a).

\section{REFERÊNCIAS}

BATISTA, F. Ferreira; PRADO, A. G. da Silva e Bonoli, E. Luís, (2012), "Avaliação das propriedades para investimento: Uma análise dos fatores que influenciam na decisão entre valor justo e modelo de custo", $12 .{ }^{\circ}$ Congresso USP - Controladoria e Contabilidade.

NABAIS, José Casalta (2010), Direito Fiscal, $6^{a}$ Ed., Coimbra, Almedina.

PEREIRA, M. H. de Freitas (2009), Fiscalidade, 3. ${ }^{a}$ Ed., Coimbra, Almedina.

PEREIRA, M. H. de Freitas (1988), "A Periodização do Lucro Tributável”, Cadernos de Ciência e Técnica Fiscal, Janeiro-Março.

RODRIGUES, Ana Maria (Coord.) (2012a), SNC - Sistema de Normalização Contabilística, 2. ${ }^{\text {Ed., }}$ Coimbra, Almedina.

RODRIGUES, Ana Maria Gomes (2012b), Propriedades de Investimento - Algumas Reflexões Contabilísticas e Fiscais, Revista de Direito Público e Fiscal, IDEFF, Faculdade de Direito da Universidade de Lisboa, Março, 12, p.: 193-225

RODRIGUES, Ana Maria Gomes (2011a), Justo Valor: uma Perspectiva Crítica e Multidisciplinar, Miscelâneas do IDET, Faculdade de Direito da Universidade de Coimbra, Coimbra, Almedina, n. ${ }^{\circ}$ 7, Setembro, p.: 69-133.

RODRIGUES, Ana Maria Gomes (2011b), Activos Intangíveis: Algumas Reflexões Contabilísticas e Fiscais, Estudos em Memória do Prof. Doutor Saldanha Sanches, Coimbra, Coimbra Editora, Vol. IV, p. 469-520.

RODRIGUES, Ana Maria; Carvalho, Carla; Cravo, Domingos e Azevedo, Graça (2011c), Contabilidade Financeira - Aplicações em Contexto de SNC, 2. ${ }^{a}$ Ed., Coimbra, Almedina.

SANCHES, J. L. Saldanha (2007), Manual de Direito Fiscal, 3. ${ }^{a}$ Ed., Coimbra, Coimbra Editora. 
SANCHES, J. L. Saldanha (1995), “A quantificação da obrigação tributária, deveres de cooperação, autoavaliação e avaliação administrativa”, Cadernos de Ciência e Técnica Fiscal, n. ${ }^{\circ} 173$.

TAVARES, Tomás Cantista (2011), IRC e Contabilidade - Da Realização ao Justo Valor, Coimbra, Almedina.

TAVARES, Tomás C. Castro (1999), "Da relação de Dependência Parcial entre a Contabilidade e o Direito Fiscal na Determinação do Rendimento Tributável das Pessoas Colectivas: Algumas Reflexões ao nível dos Custos", Cadernos de Ciência e Técnica Fiscal, n. 396, OutubroDezembro.

VASCONCELOS, André A. (2011), “O Justo Valor e o Código do IRC”, Revista Finanças Públicas e Direito Fiscal, Janeiro, p. 191-208. 